\title{
PENGARUH EARNING PER SHARE (EPS) DAN PRICE EARNING RATIO (PER) TERHADAP RETURN SAHAM PADA PERUSAHAAN LQ45 PERIODE 2017-2019
}

\author{
${ }^{1}$ Khairaningrum Mulyanti, ${ }^{2}$ Amy Arsy Prasetyami Randus \\ Program Studi D4 Akuntansi Keuangan \\ Politeknik Pos Indonesia \\ khairaningrum@poltekpos.ac.id, amyarsy35@gmail.com
}

\begin{abstract}
ABSTRAK
Perusahaan yang memiliki kinerja cukup baik akan lebih diminati oleh para investor. Kinerja perusahaan yang meningkat akan berpengaruh pada meningkatnya harga saham dan diharapkan return saham yang diterima investor meningkat. Salah satu kelompok perusahaan yang diminati oleh para investor adalah perusahaan-perusahaan yang masuk kedalam indeks LQ45. Penelitian ini bertujuan untuk mengetahui pengaruh earning per share dan price earning ratio terhadap return saham baik secara parsial maupun simultan. Metode yang digunakan dalam penelitian ini adalah metode kuantitatif dengan jenis perumusan masalah asosiatif. Populasi dalam penelitian ini adalah perusahaan LQ45 yang terdaftar di BEI. Berdasarkan kriteria yang ada, pengambilan sampel dilakukan dengan teknik purposive sampling. Teknik analisis data yang digunakan dalam penelitian ini adalah uji normalitas data, korelasi product moment, korelasi berganda, regresi linier berganda, koefisien determinasi, uji t-test, dan uji f-test. Hasil penelitian ini menunjukkan baik secara parsial maupun simultan variabel earning per share dan variabel price earning ratio tidak memiliki pengaruh yang signifikan terhadap return saham.
\end{abstract}

Kata Kunci: Earning Per Share (EPS), Price Earning Ratio (PER), Return Saham

\section{ABSTRACT}

Companies that have a fairly good performance will increasingly attract investors. Increasing company performance will have an impact on increasing stock prices and it is expected that the stock returns received by investors will increase. One of the group companies that investors are interested in are companies that are included in the LQ45 index. This thesis aims to determine the effect of earning per share and price earning ratio on stock returns either partially or simultaneously. The method used in this research is a quantitative method with the type of associative problem formulation. The population in this study are the LQ45 companies listed on the IDX. Based on the existing criteria, the sample was taken by using purposive sampling technique. The data analysis technique used in this research is data normality test, product moment correlation, multiple correlation, multiple linear regression, coefficient of determination, $t$-test, and f-test. The results of this study indicate that both partially and simultaneously the variable earning per share and the variable price earning ratio do not have a significant effect on stock returns.

Keywords: Earning Per Share, Price Earning Ratio, Stock Returns

\section{PENDAHULUAN}

Seperti yang kita tahu Indonesia merupakan negara yang memiliki banyak jenis perusahaan yang pada umumnya berdiri dengan tujuan untuk meningkatkan nilai perusahaan tersebut secara maksimal bagi para shareholders, yang biasanya dilihat dengan harga suatu saham perusahaan dari waktu ke waktu. Harga saham sangat berguna 
bagi calon investor yang akan melakukan investasi, karena menjadi salah satu parameter value yang dimiliki oleh sebuah perusahaan. Dengan harga saham yang baik, maka tujuan para investor dalam berinvestasi akan tercapai. Tujuan investor dalam menginvestasikan adalah untuk memperoleh imbal hasil (return) yang tinggi yang dapat dilakukan melalui pasar modal.

Bagi para investor, return merupakan salah satu parameter untuk menilai seberapa besar keuntungan suatu saham (capital gain). Namun, investorpun harus siap menghadapi risiko yang mungkin saja dapat dialami oleh investor dalam bentuk kerugian (capital loss). Oleh karena itu, sebagai investor harus mampu mencari sumber informasi guna dilakukan suatu penilaian dan membuat kebijakan dalam memilih investasi.

Informasi merupakan hal terpenting bagi investor untuk menilai kinerja perusahaan. Investor yang akan berinvestasi di pasar modal terlebih dahulu melihat saham perusahaan mana yang paling menguntungkan, dengan menilai kinerja perusahaan yang bersangkutan. Perusahaan yang memiliki kinerja cukup baik akan lebih diminati oleh para investor, karena kinerja perusahaan mempengaruhi harga saham dipasar. Investor akan membeli saham sesuai dengan kinerja perusahaan saat ini dan prospeknya dimasa yang akan datang. Kinerja perusahaan yang meningkat akan berpengaruh pada meningkatnya harga saham dan diharapkan return saham yang diterima investor meningkat.

Dilansir dari (CNBC indonesia pada tanggal 01 Oktober 2018 17:25 WIB) kinerja 45 saham paling likuid (LQ45) di bursa saham Indonesia sepanjang sembilan bulan pertama tahun ini konsisten bertahan di zona merah. Hingga akhir September lalu indeks LQ45 tercatat terkoreksi $12,34 \%$, turun lebih dalam dibanding dengan kinerja Indeks Harga Saham Gabungan (IHSG) pada periode yang sama. Dari 45 saham tersebut, tercatat hanya sembilan saham yang mencatatkan kinerja positif sejak awal tahun lalu. Salah satu yang mendorong pelemahan indeks LQ45 yaitu koreksi saham-saham dari sektor konstruksi. Sektor konstruksi memang sedang mendapat tekanan tahun ini, yang tercermin dari penurunan indeks sektor ini sebesar 12,17\%. Emiten sektor konstruksi, khususnya perusahaan konstruksi Badan Usaha Milik Negara (BUMN), yang sempat mendapatkan sentimen negatif dari investor. Penyebabnya adalah kenaikan nilai utang yang tinggi karena mengerjakan proyek infrastruktur. Ada kekhawatiran kenaikan beban terebut menambah beban keuangan emiten dari sektor ini. Saham-saham yang mengalami penurunan dalam pada periode ini tercatat atas saham PT AKR Corporindo Tbk (AKRA) turun $38,74 \%$, hal ini disebabkan antara lain turunnya pendapatan sebesar $13,37 \%$, lalu beban usaha yang naik juga menjadikan faktor tergerusnya laba bersih perusahaan diperiode ini dan PT Media Nusantara Citra Tbk (MNCN) terkoreksi 37,35\%. Sedangkan saham-saham yang terkoreksi selama 9 bulan pertama 2018, diantaranya saham PT Indah Kiat Pulp \& Paper Tbk (INKP) yang naik 218,06\%, PT Bukit Asam Tbk (PTBA) naik $78,86 \%$, saham PT Aneka Tambang Tbk (ANTM) naik 32\% dan saham PT Perusahaan Gas Negara Tbk (PGAS) yang naik $28 \%$.

Tabel 1.1 Penurunan Harga Penutupan Saham Perusahaan LQ45

\begin{tabular}{|c|c|c|c|}
\hline Kode Perusahaan & Tahun 2017 & Tahun 2018 & Tahun 2019 \\
\hline INTP & 21,950 & 18,450 & 19,025 \\
\hline AKRA & 6,350 & 4,290 & 3,950 \\
\hline MNCN & 1,285 & 690 & 1,630 \\
\hline
\end{tabular}

Berdasarkan tabel diatas dapat disimpulkan harga saham merupakan unsur penting bagi return saham. Apabila harga saham menurun maka return saham sebuah perusahaan akan ikut menurun ataupun negatif, investorpun tidak akan mendapatkan keuntungan. 
Kinerja perusahaan dapat diukur menggunakan analisis fundamental dimana analisis tersebut dapat membantu para investor memberikan keputusan untuk jual beli saham meliputi perhitungan nilai wajar harga saham menggunakan metode rasio-rasio keuangan. Tinggi rendahnya harga saham juga merupakan refleksi dari keputusan investasi, keputusan pendanaan dan pengelolaan aset suatu perusahaan. Dalam rangka melihat besar keuntungan yang bisa diperoleh dari pertumbuhan perusahaan, investor dapat mempertimbangkan hasil perhitungan earnings per share (EPS) perusahaan.

(Rahmawati, 2017) menyatakan "Semakin kecil nilai laba per saham maka semakin kecil pula kemungkinan perusahaan untuk membagikan dividen". Maka dapat dikatakan investor akan lebih meminati saham yang memiliki earning per share tinggi dibandingkan saham yang memiliki earning per share rendah. Tak hanya itu, Earning Per Share (EPS) juga berfungsi sebagai komponen utama yang digunakan untuk menghitung penilaian Price Earning Ratio (PER) .

(Gitman, 2015) menjelaskan "Perusahaan yang memiliki PER yang tinggi biasanya memiliki peluang tingkat pertumbuhan yang tinggi, sehingga menyebabkan ketertarikan investor untuk membeli saham perusahaan yang kemudian dapat meningkatkan harga saham". Peningkatan harga saham yang terjadi akan direspon positif oleh para investor karena mereka akan memperoleh capital gain yang merupakan salah satu komponen return saham .

Berdasarkan latar belakang yang telah dijabarkan, penelitian ini dilakukan untuk mengetahui apakah terdapat pengaruh antara earning per share (eps) dan price earning ratio (per) terhadap return saham baik secara parsial maupun simultan. Terdapat juga beberapa penelitian terdahulu yang digunakan untuk menjadi referensi penelitian ini yaitu berdasarkan hasil (Wuldani, 2016) tentang Pengaruh Price Earning Ratio (PER) dan Earning Per Share (EPS) terhadap Return Saham. (Rifa, 2017) tentang Pengaruh Earning Per Share (EPS) dan Price Earning Ratio (PER) terhadap Return Saham dan (Susiani, 2017) tentang Pengaruh Earning Per Share (EPS) dan Price Earning Ratio (PER) terhadap Return Saham, hal ini sejalan dengan teori menurut (Suwardjono, 2014) menyatakan "hipotesis pasar efisien mengisyaratkan bahwa tidak seorangpun akan memperoleh return lebih hanya atas pengetahuannya terhadap data laba dan menurut (Mathilda, 2017) menyatakan "PER mencerminkan penilaian pasar terhadap saham yang digunakan untuk menentukan apakah harga saham tertentu dinilai terlalu rendah atau terlalu tinggi" yang artinya tidak semua investor dapat melihat return dengan menentukan harga saham saja melainkan bukan dilihat dari kinerja perusahaan tersebut.

\section{KAJIAN PUSTAKA}

\section{Earning Per Share (EPS)}

(Tandelilin, 2017) menyatakan "Earning Per Share (EPS) menujukkan besarnya laba bersih perusahaan yang siap dibagikan bagi semua pemegang saham perusahaan". Adapun rumus untuk mencari Earning Per Share (EPS) yang dikemukakannya, sebagai berikut:

$$
E P S=\frac{\text { Laba Bersih Setelah Pajak }}{\text { Jumlah Saham yang Beredar }}
$$

\section{Gambar 2.1 Rumus Earning Per Share (EPS)}

\section{Price Earning Ratio (PER)}

(Tandelilin, 2017) menyatakan "Price Earning Ratio (PER) mengindikasikan banyaknya rupiah dari laba yang saat ini investor bersedia membayar sahamnya, Dengan 
kata lain PER merupakan harga untuk tiap rupiah laba". Adapun rumus untuk mencari Price Earning Ratio (PER) yang dikemukakannya, sebagai berikut:

$$
\text { PER atau P/E Ratio }=\frac{\text { Harga Saham }}{E P S}
$$

\section{Return Saham}

\section{Gambar 2.2 Rumus Price Earning Ratio (PER)}

(Hartono, 2017) menyatakan "Return Saham adalah hasil keuntungan yang diperoleh oleh investor dari suatu investasi saham yang dilakukan. Return saham dapat berupa return realisasi yang sudah terjadi atau return ekspektasi yang belum terjadi tetapi yang diharapakan akan terjadi dimasa datang". Adapun rumus return saham yang dikemukakannya sebagai berikut:

$$
\text { Return }=R t=\frac{P_{t}-P_{t-1}}{P_{\mathrm{t}-1}}
$$

\section{Gambar 2.3 Rumus Return Saham}

\section{METODE PENELITIAN Jenis Penelitian}

Metode penelitian ini menggunakan metode penelitian kuantitatif, dengan jenis penelitian assosiatif dengan bentuk hubungan kausal. Hubungan kausal merupakan hubungan yang bersifat sebab-akibat.

\section{Operasionalisasi Variabel}

Terdapat 3 (tiga ) variabel dalam penelitian ini berdasarkan judul penelitian yaitu "Pengaruh Earning Per Share (EPS) dan Price Earning Ratio (PER) terhadap Return Saham Pada Perusahaan LQ45 Periode 2017-2019" maka variabel dalam peneltian ini adalah variabel independen earning per share $(\mathrm{eps})\left(\mathrm{X}_{1}\right)$, price earning ratio (per) $\left(\mathrm{X}_{2}\right)$, dan variabel dependen return saham (Y).

Operasionalisasi variabel diperlukan untuk menentukan jenis dan indikator dari variabel-variabel yang terkait dalam penelitian ini.

\section{Teknik Pengumpulan Data}

Data yang digunakan dalam penelitian ini merupakan data sekunder dengan pengumpulan data menggunakan teknik studi dokumentasi. Data diakses melalui situs resmi www.idx.co.id dan web resmi perusahaan. Peneliti juga menggunakan studi dokumentasi sebagai acuan dan dasar teori dalam mengolah data yang dibutuhkan untuk penelitian.

\section{Populasi dan Sampel}

Populasi dalam penelitian ini adalah seluruh perusahaan LQ45 yang terdaftar di Bursa Efek Indonesia yang berjumlah 45 perusahaan .

"Dengan menggunakan metode non probability sampling dengan teknik purposive sampling peneliti mengambil 10 (sepuluh) perusahaan selama 3 (tiga) tahun periode sehingga total sampel yang diteliti sebanyak 30 sampel.

\section{Teknik Analisis Data}

Penelitian ini menggunakan 7 (tujuh) teknik analisis yaitu: uji normalitas, analisis korelasi product moment, analisis korelasi berganda, analisis regresi linier berganda, analisis koefisien determinasis, uji T-test dan uji F-test dengan menggunakan bantuan SPSS (Statistical Product and Service Solutions) versi 25.0. 


\section{HASIL DAN PEMBAHASAN \\ Uji Normalitas Data}

Uji normalitas dilakukan untuk menguji apakah dalam model regresi variabel independen dan variabel dependen atau keduanya mempunyai distribusi normal atau tidak. Dasar pengambilan keputusan dalam penelitian ini adalah bila nilai $s i g>0,05$,maka data berdistribusi normal dan jika nilai $\operatorname{sig}<0,05$, maka data tidak berdistribusi normal.

Berdasarkan atas pengolohan data yang dilakukan peneliti dalam penelitian ini, maka hasil uji normalitas dapat terlihat pada tabel berikut:

\section{Tabel 4.1 Hasil Uji Normalitas}

\begin{tabular}{|c|c|c|c|}
\hline \multicolumn{4}{|c|}{ One-Sample Kolmogorov-Smirnov Test } \\
\hline & & & $\begin{array}{l}\text { Unstandardized } \\
\text { Residual }\end{array}$ \\
\hline & \multicolumn{2}{|l|}{$\mathrm{N}$} & 30 \\
\hline & \multirow[t]{2}{*}{ Normal Parameters } & Mean & .0000000 \\
\hline & & Std. Deviation & .38310081 \\
\hline & \multirow[t]{3}{*}{ Most Extreme Differences } & Absolute & .150 \\
\hline & & Positive & .150 \\
\hline & & Negative & -.066 \\
\hline & \multicolumn{2}{|l|}{ Test Statistic } & .150 \\
\hline A & \multicolumn{2}{|l|}{ symp. Sig. (2-tailed) } & $.082^{\mathrm{c}}$ \\
\hline $\begin{array}{l}\text { a. } \\
\text { b. }\end{array}$ & $\begin{array}{l}\text { Test distribution is Normal } \\
\text { Calculated from data. } \\
\text { Lilliefors Significance Corn }\end{array}$ & ion. & \\
\hline
\end{tabular}

Dari hasil uji normalitas yang dilakukan bahwa setiap variabel memiliki nilai Asymtotic Significanted (2-tailed) sebesar 0,082 dimana hal tersebut menunjukkan jika nilai tersebut lebih besar dari nilai 0,05 dinyatakan terdistribusi normal. Dimana hal tersebut menunjukkan 0,082 >0,05 maka dengan demikian data tersebut dinyatakan berditribusi normal. Apabila data sudah dinyatakan berdistribusi normal, maka dapat dilanjutkan ke alat uji analisis selanjutnya yang telah ditentukan yaitu analisis korelasi product moment, analisis korelasi berganda, analisis regresi linier berganda, analisis koefisien determinasi, uji t-test, dan uji f-test.

\section{Analisis Korelasi Product Moment}

Analisis Korelasi Product Moment digunakan untuk mengukur apakah terdapat hubungan yang kuat antara variabel independent terhadap variabel dependen secara parsial. Berikut tabel hasil analisis korelasi product moment dengan menggunakan IBM SPSS Statistic 25.0:

\section{Tabel 4.2 Hasil Analisis Korelasi Product Moment}




\begin{tabular}{|c|c|c|c|c|}
\hline \multicolumn{5}{|c|}{ Correlations } \\
\hline & & $\begin{array}{l}\text { Earning Per } \\
\text { Share }\end{array}$ & $\begin{array}{l}\text { Price Earning } \\
\text { Ratio }\end{array}$ & Return Saham \\
\hline \multirow[t]{3}{*}{ Earning Per Share } & $\begin{array}{c}\text { Pearson } \\
\text { Correlation }\end{array}$ & 1 & -.286 & -.057 \\
\hline & Sig. (2-tailed) & & .125 & .766 \\
\hline & $\mathrm{N}$ & 30 & 30 & 30 \\
\hline \multirow{3}{*}{$\begin{array}{l}\text { Price Earning } \\
\text { Ratio }\end{array}$} & Pearson Correlation & -.286 & 1 & -.140 \\
\hline & Sig. (2-tailed) & .125 & & .460 \\
\hline & $\mathrm{N}$ & 30 & 30 & 30 \\
\hline \multirow[t]{3}{*}{ Return Saham } & Pearson Correlation & -.057 & -.140 & 1 \\
\hline & Sig. (2-tailed) & .766 & .460 & \\
\hline & $\mathrm{N}$ & 30 & 30 & 30 \\
\hline
\end{tabular}

Dari hasil korelasi product moment yang dilakukan bahwa nilai hubungan antara earning per share (X1) terhadap return saham (Y) sebesar -0,057. (Sugiyono, 2017) menyatakan nilai tersebut sesuai dengan pedoman tabel interpretasi koefisien korelasi berada pada rentan interval antara $0,00-0,199$ yang artinya memiliki hubungan yang sangat rendah. Sedangkan nilai hubungan price earning ratio (X2) terhadap return saham (Y) sebesar -0,140. Maka nilai tersebut berada pada interval koefisien 0,00-0,199 yang artinya memiliki hubungan yang sangat rendah.

\section{Analisis Korelasi Berganda}

Korelasi berganda merupakan angka yang menunjukkan arah dan kuatnya hubungan antara dua variabel independen earning per share $\left(\mathrm{X}_{1}\right)$, price earning ratio $\left(\mathrm{X}_{2}\right)$ secara bersama-sama atau simultan dengan satu variabel dependen return saham (Y). Dalam menentukan korelasi berganda pada penelitian ini menggunakan bantuan program aplikasi SPPS versi 25.0 dengan hasil sebagai berikut:

\section{Tabel 4.3 Hasil Analisis Korelasi Berganda}

\begin{tabular}{|c|c|c|c|c|c|c|c|c|c|}
\hline \multirow[b]{2}{*}{ Model } & \multirow[b]{2}{*}{$\mathrm{R}$} & \multicolumn{7}{|c|}{ Model Summary } & \\
\hline & & $\begin{array}{r}\mathrm{R} \\
\text { Square }\end{array}$ & $\begin{array}{l}\text { Adjusted R } \\
\text { Square }\end{array}$ & $\begin{array}{l}\text { Std. Error of the } \\
\text { Estimate }\end{array}$ & $\begin{array}{l}\text { R Square } \\
\text { Change }\end{array}$ & $\begin{array}{c}\text { Change St } \\
\text { F } \\
\text { Change }\end{array}$ & atistic & $\begin{array}{c}\mathrm{d} \\
\mathrm{df} 2\end{array}$ & $\begin{array}{l}\text { Sig. } \\
\text { F } \\
\text { Change }\end{array}$ \\
\hline 1 & $.173^{\mathrm{a}}$ & .030 & -.042 & .397036 & .030 & .416 & 2 & 27 & .664 \\
\hline
\end{tabular}

Dari hasil pengelohan data menggunakan SPSS versi 25.0 maka dapat diketahui Pengaruh Earning Per Share (EPS) dan Price Earning Ratio (PER) terhadap Return Saham secara bersama-sama atau simultan dapat dilihat nilai R nya sebesar 0,173 , hal ini menunjukkan bahwa variabel independent mempunya nilai korelasi berganda yang berada pada interval $0,00-0,199$ yaitu sangat rendah.

\section{Analisis Regresi Linier Berganda}

Analisis regresi linier berganda digunakan apabila peneliti bermaksud meramalkan bagaimana keadaan (naik turunnya) variabel dependen (kriterium), bila dua atau lebih variabel independen sebagai faktor prediktor dimanipulasi (dinaik turunkan nilainya) . 
Analisis ini digunakan untuk menentukan sejauh mana return saham dipengaruhi oleh earning per share (eps) dan price earning ratio (per). . Berikut adalah hasil dari analisis regresi linear berganda yang telah dilakukan peneliti:

Tabel 4.4 Hasil Regresi Liniear Berganda

\begin{tabular}{|c|c|c|c|c|c|c|}
\hline \multicolumn{7}{|c|}{ Coefficients $^{a}$} \\
\hline \multirow{2}{*}{\multicolumn{2}{|c|}{ Model }} & \multicolumn{2}{|c|}{ Unstandardized Coefficients } & \multirow{2}{*}{$\begin{array}{c}\text { Standardized } \\
\text { Coefficients } \\
\text { Beta } \\
\end{array}$} & \multirow[b]{2}{*}{$\mathrm{t}$} & \multirow[b]{2}{*}{ Sig. } \\
\hline & & B & Std. Error & & & \\
\hline \multirow[t]{3}{*}{1} & (Constant) & .094 & .150 & & .625 & .538 \\
\hline & Earning Per Share & .000 & .000 & -.106 & -.533 & .598 \\
\hline & Price Earning Ratio & -.002 & .002 & -.170 & -.861 & .397 \\
\hline
\end{tabular}

Dari hasil diatas, maka menghasilkan persamaan sebagai berikut:

$$
\begin{gathered}
\mathrm{Y}=\mathrm{a}+\mathrm{b}_{1} \mathrm{X}_{1}+\mathrm{b}_{2} \mathrm{X}_{2} \\
\mathrm{Y}=0,094+0,000 \mathrm{X}_{1}+(-0,002) \mathrm{X}_{2}
\end{gathered}
$$

Dimana:

$\mathrm{a}=$ konstanta, $\mathrm{b}_{1} \mathrm{~b}_{2}=$ koefisien regresi, $\mathrm{Y}=$ Return Saham, $\mathrm{X}_{1}=$ Earning Per Share, $\mathrm{X}_{2}=$ Price Earning Ratio

Berdasarkan persamaan regresi linear berganda diatas, maka dapat disimpulkan sebagai berikut:

1. Jika variabel earning per share $\left(\mathrm{X}_{1}\right)$ dan price earning ratio $\left(\mathrm{X}_{2}\right)$ nilainya adalah 0 , maka nilai variabel return saham (Y) adalah sebesar konstanta atau sebesar 0,094.

2. Nilai koefisien regresi variabel earning per share (X1) sebesar 0,000 artinya jika variabel independent lain nilainya tetap dan earning per share mengalami kenaikan 1 satuan, maka return saham akan mengalami kenaikan sebesar 0,000. Karena koefisien bernilai positif maka akan terjadi hubungan yang positif pula antara earning per share $\left(\mathrm{X}_{1}\right)$ terhadap return saham $(\mathrm{Y})$, jadi kenaikan earning per share akan mengakibatkan kenaikan return saham.

3. Nilai koefisien regresi variabel price earning ratio $\left(\mathrm{X}_{2}\right)$ sebesar $-0,002$ artinya jika variabel independent lain nilainya tetap dan price earning ratio mengalami kenaikan 1 satuan, maka return saham akan mengalami penurunan sebesar -0,002. Karena koefisien bernilai negatif maka akan terjadi hubungan yang negatif pula antara price earning ratio $(\mathrm{X} 2)$ terhadap return saham $(\mathrm{Y})$, jadi kenaikan price earning ratio akan mengakibatkan penurunan pada return saham.

\section{Analisis Koefisien Determinasi}

Analisis koefisien determinasi digunakan untuk mengetahui besarnya peresentase pengaruh variabel independent terhadap variabel dependen. Berikut tabel hasil analisis koefisien determinasi menggunakan IBM SPSS Statistic versi 25.0:

Tabel 4.5 Hasil Koefisien Determinasi

\begin{tabular}{|l|l|l|l|l|l|}
\hline \multicolumn{9}{|c|}{ Model Summary } \\
\hline & & $\mathrm{R}$ & Adjusted & Std. Error of & Change Statistics \\
\hline
\end{tabular}




\begin{tabular}{|c|c|c|c|c|c|c|c|c|c|}
\hline Model & $\mathrm{R}$ & Square & R Square & the Estimate & $\begin{array}{c}\mathrm{R} \\
\text { Square } \\
\text { Change }\end{array}$ & $\begin{array}{c}\mathrm{F} \\
\text { Change }\end{array}$ & df1 & $\mathrm{df} 2$ & $\begin{array}{l}\text { Sig. F } \\
\text { Change }\end{array}$ \\
\hline 1 & $.173^{\mathrm{a}}$ & .030 & $\begin{array}{l}.042 \\
\end{array}$ & .397036 & .030 & .416 & 2 & 27 & .664 \\
\hline
\end{tabular}

Berdasarkan tabel diatas dapat diketahui bahwa R Square adalah sebesar 0,030. Nilai ini dikenal dengan koefisien determinasi $(\mathrm{Kd})$ yang dapat dihitung sebagai berikut: $\mathrm{Kd}=\mathrm{r}^{2} \times 100 \%$ $\mathrm{Kd}=0,030 \times 100 \%$ $\mathrm{Kd}=3 \%$

Berdasarkan nilai perolehan R2 (R Square) sebesar 0,030 atau $3 \%$. Hal ini menunjukkan bahwa persentase pengaruh variabel independent earning per share $\left(\mathrm{X}_{1}\right)$ dan price earning ratio $\left(\mathrm{X}_{2}\right)$ terhadap return saham $(\mathrm{Y})$ adalah $3 \%$ sedangkan sisanya sebesar $97 \%$ dipengaruhi oleh faktor lainnya yang tidak dimasukkan ke dalam penelitian ini.

\section{Uji T}

Pengujian hipotesis Uji $\mathrm{t}$ digunakan dalam pengujian dimana dua atau lebih variabel independen berpengaruh secara parsial (tidak bersamaan). Dalam penelitian ini uji t digunakan untuk menguji pengaruh earning per share $\left(\mathrm{X}_{1}\right)$ terhadap return saham, dan price earning ratio $\left(\mathrm{X}_{2}\right)$ terhadap return saham. Dalam penelitian ini menggunakan uji dua pihak (two tails test). Syarat penerimaan hipotesis menggunakan uji-t ini adalah sebagai berikut:

a. Ho ditolak, Ha diterima : apabila $t_{\text {hitung }} \geq t_{\text {tabel }}$ atau $-t_{\text {hitung }} \leq-t_{\text {tabel }}$

b. Ho diterima, Ha ditolak : apabila $\mathrm{t}_{\text {hitung }} \leq \mathrm{t}_{\text {tabel }}$ atau $-\mathrm{t}_{\text {hitung }} \geq-\mathrm{t} \mathrm{t}_{\mathrm{abel}}$

Tabel 4.6 Hasil Uji T

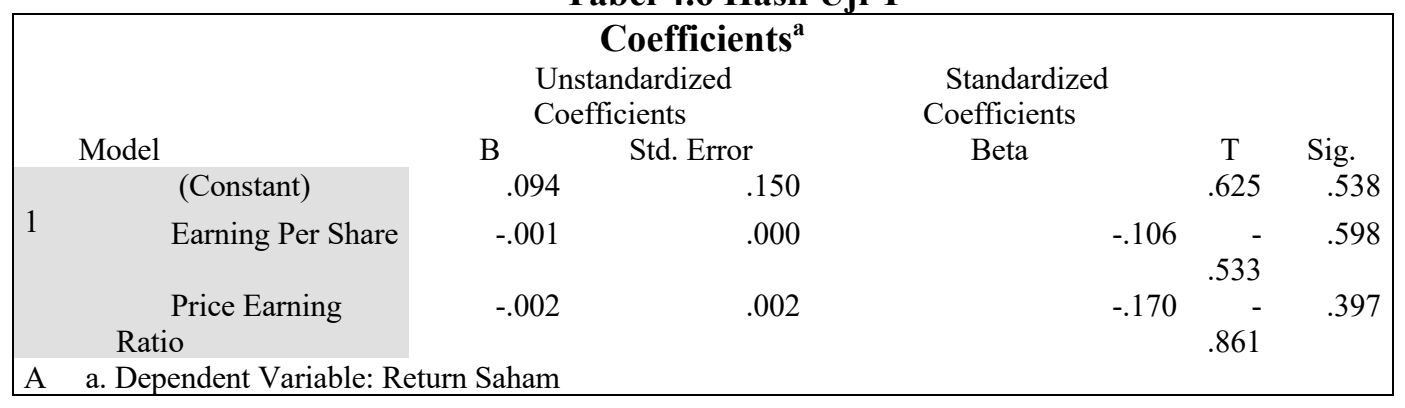

Dari hasil perhitungan diatas menunjukkan bahwa nilai -t hitung pengaruh earning per share terhadap return saham sebesar $-0,533$ Dengan melihat pada $t$ tabel jumlah data $\mathrm{n}=30$ dan $(\mathrm{df})=\mathrm{n}-\mathrm{k}-1$ atau 30-2-1 $=27$ pada tingkat kesalahan $\alpha=0,05$ dengan pengujian dua pihak maka diperoleh $-\mathrm{t}$ tabel sebesar $-2,052$, dimana nilai $-\mathrm{t}$ hitung lebih besar dari $-\mathrm{t}$ tabel $(-0,533 \geq-2,052)$ dan signifikansi $>0,05(0,598>0,05)$ maka hal ini menunjukkan bahwa Ho diterima dan Ha ditolak dan dapat disimpulkan bahwa secara parsial earning per share tidak berpengaruh signifikan terhadap return saham pada Perusahaan indeks LQ45 yang terdaftar di Bursa Efek Indonesia (BEI) periode 2017-2019.

Sedangkan hasil pengujian Price Earning Ratio (PER) terhadap Return Saham menunjukkan $-\mathrm{t}$ hitung sebesar $-0,861$ dan signifikansi 0,397 dengan melihat pada $t$ tabel jumlah data $\mathrm{n}=30$ dan $(\mathrm{df})=\mathrm{n}-\mathrm{k}-1$ atau $30-2-1=27$ pada tingkat kesalahan $\alpha=0,05$ dengan pengujian dua pihak maka diperoleh nilai $-\mathrm{t}$ tabel sebesar $-2,052$, dimana nilai $-\mathrm{t}$ hitung lebih besar dari $-\mathrm{t}_{\text {tabel }}(-0,861 \geq-2,052)$ dan signifikansi $>0,05(0,397>0,05)$ 
maka Ho diterima dan Ha ditolak dan dapat disimpulkan bahwa secara parsial price earning ratio tidak berpengaruh signifikan terhadap return saham pada Perusahaan indeks LQ45 yang terdaftar di Bursa Efek Indonesia (BEI) periode 2017-2019. Secara visual daerah penerimaan dan penolakan Ha dapat dilihat pada gambar berikut:

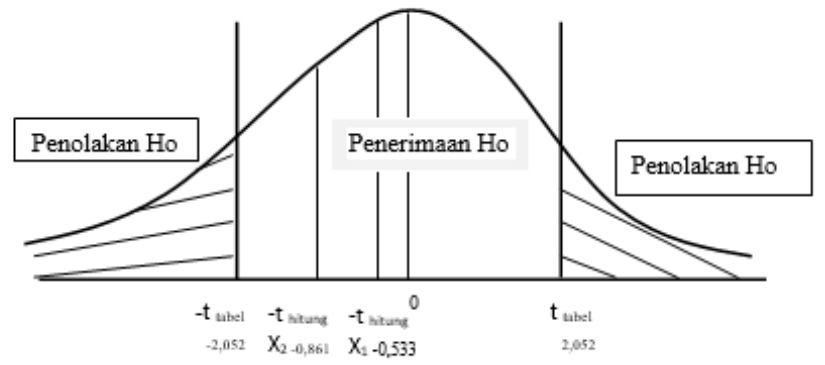

\section{Uji F}

\section{Gambar 1 Kurva Uji T}

Pengujian hipotesis Uji F digunakan untuk mengetahui pengaruh dari seluruh variabel independent secara bersama-sama terhadap variabel dependen yaitu apakah terdapat pengaruh earning per share (eps) dan price earning ratio (per) terhadap return saham secara simultan atau bersama-sama. Uji $\mathrm{F}$ dilakukan dengan cara membandingkan $F_{\text {hitung }}$ dengan $F_{\text {tabel }}$, pedoman pengambilan keputusan hasil uji $\mathrm{f}$ adalah sebagai berikut:

a. Ha diterima, Ho ditolak: apabila probabilitas (signifikan) $<0,05(\alpha)$ atau $F_{\text {hitung }}>$ $F_{\text {tabel. }}$.

b. Ha ditolak, Ho diterima: apabila probabilitas (signifikan) $>0,05(\alpha)$ atau $\mathrm{F}_{\text {hitung }}<$ $\mathrm{F}_{\text {tabel. }}$

Berikut ini adalah tabel hasil dari uji F dalam menggunakan SPPS Statistic versi 25.0 :

Tabel 4.7 Hasil Uji F

\begin{tabular}{|c|c|c|c|c|c|c|}
\hline \multicolumn{7}{|c|}{$\mathbf{A N O V A}^{\mathbf{a}}$} \\
\hline \multicolumn{2}{|c|}{ Model } & $\begin{array}{l}\text { Sum of } \\
\text { Squares }\end{array}$ & Df & Mean Square & $\mathrm{F}$ & Sig. \\
\hline \multirow[t]{3}{*}{1} & Regression & .131 & 2 & .066 & .416 & $.664^{\mathrm{b}}$ \\
\hline & Residual & 4.256 & 27 & .158 & & \\
\hline & Total & 4.387 & 29 & & & \\
\hline
\end{tabular}

Berdasarkan perhitungan SPSS versi 25.0, maka dapat nilai $F_{\text {hitung }}$ sebesar 0,461 dan signifikansi 0,664 dengan $(\mathrm{dk}=\mathrm{n}-\mathrm{k}-1$ yaitu $30-2-1=27)$ dimana tingkat signifikansi $5 \%$ maka diperoleh nilai $\mathrm{F}_{\text {tabel }}$ sebesar 2,052 sehingga $\mathrm{F}_{\text {hitung }} \leq \mathrm{F}_{\text {tabel }}(0,461 \leq 2,052)$ dan signifikansi $>0,05(0,664>0,05)$ maka Ho diterima dan Ha ditolak . Dengan demikian dapat disimpulkan bahwa secara simultan tidak terdapat pengaruh signifikan antara Earning Per Share dan Price Earning Ratio terhadap Return Saham pada Perusahaan LQ45 yang terdaftar di Bursa Efek Indonesia (BEI) periode 2017-2019. Secara visual daerah penerimaan dan penolakan Ho dapat dilihat pada gambar berikut: 


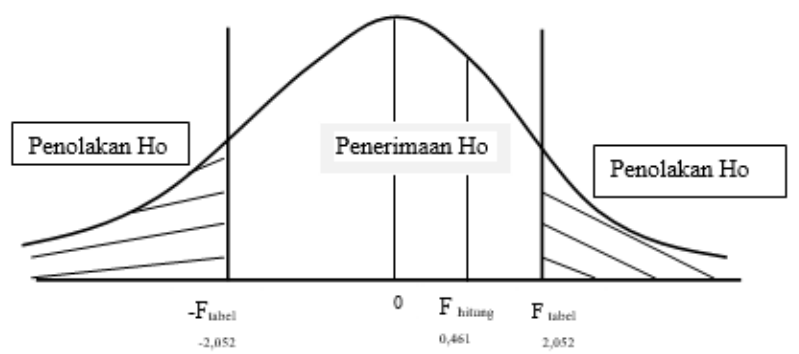

Gambar 2 Kurva Uji F

\section{PEMBAHASAN}

\section{Pengaruh Earning Per Share (EPS) terhadap Return Saham}

Berdasarkan hasil analisis uji hipotesis $t$-test secara parsial earning per share (eps) memiliki $-t_{\text {hitung }}$ sebesar $-0,533$ dan $t_{\text {tabel }}-2,052$ yang artinya nilai $-t_{\text {hitung }}$ lebih besar dari $t_{\text {tabel }}(-0,533 \geq-2,052)$ dan signifikansi $>0,05(0,598>0,05)$ maka Ho diterima dan Ha ditolak dan dapat disimpulkan bahwa secara parsial earning per share (eps) tidak terdapat pengaruh signifikan terhadap return saham pada Perusahaan LQ45 Periode 2017-2019 .

Berdasarkan teori menurut Suwardjono (2014) menyatakan bahwa "Hipotesis Pasar efisien mengisyaratkan bahwa tidak seorangpun akan memperoleh return lebih hanya atas pengetahuannya terhadap data laba". Hal ini menunjukkan bahwa meskipun perusahaan mencetak laba bersih tinggi ataupun mengalami kenaikan belum tentu akan memberikan peningkatan terhadap return saham.

Ini artinya earning per share memiliki unsur laba didalamnya, hal ini menunjukkan bahwa meskipun data laba pada perusahaan mengalami peningkatan belum tentu akan memberikan peningkatan terhadap return saham. Ini artinya investor tidak hanya mempertimbangkan data laba saja untuk mendapatkan return saham, namun mempertimbangkan faktor lain yang mungkin lebih mempengaruhi return saham tersebut.

Hasil Penelitian ini sejalan dengan penelitian terdahulu yang diteliti oleh (Rahmawati, 2017) tentang Pengaruh Earning Per Share (EPS), Return On Equity (ROE) dan Debt to Equity Ratio (DER) terhadap Return Saham yang menyatakan bahwa earning per share (eps) secara parsial tidak berpengaruh signifikan terhadap return saham.

\section{Pengaruh Price Earning Ratio (PER) terhadap Return Saham}

Berdasarkan hasil analisis uji hipotesis $t$-test secara parsial earning per share (eps) memiliki $-\mathrm{t}_{\text {hitung }}$ sebesar $-0,861$ dan $-\mathrm{t}_{\text {tabel }}-2,052$ yang artinya dimana nilai $-\mathrm{t}_{\text {hitung }}$ lebih besar dari $-t_{\text {tabel }}(-0,861 \geq-2,052)$ dan signifikansi $>0,05(0,397>0,05)$ maka Ho diterima dan Ho ditolak dan dapat disimpulkan bahwa secara parsial price earning ratio (per) tidak terdapat pengaruh signifikan terhadap return saham pada Perusahaan LQ45 Periode 2017-2019 .

Berdasarakan teori menurut (Mathilda, 2017) menyatakan bahwa "PER mencerminkan penilaian pasar terhadap saham yang digunakan untuk menentukan apakah harga saham tertentu dinilai terlalu rendah atau terlalu tinggi”. Ini artinya para investor dalam menentukan harga saham bukan dilihat berdasarkan kinerja perusahaan apakah mengalami keuntungan atau kerugian yang berdampak pada return yang akan didapatkan, melainkan harga saham, adanya mekanisme pasar seperti harga saham dalam suatu perusahaan terbentuk disebabkan karena adanya permintaan dan penawaran dan kondisi ekonomi di Indonesia yang tidak stabil. Dengan ketidakpastian dalam menilai harga saham suatu perusahaan ini menunjukkan hasil tidak signifikan antara rasio pasar yang diukur menggunkan price earning ratio tidak menyebabkan perubahan return saham. 
Hal ini sejalan dengan penelitian terdahulu yang diteliti oleh (Rifa, 2017) tentang Pengaruh Earning Per Share (EPS) dan Price Earning Ratio (PER) terhadap Return Saham yang menyatakan bahwa price earning ratio secara parsial tidak berpengaruh signifikan terhadap return saham.

\section{Pengaruh Earning Per Share dan Price Earning Ratio terhadap Return Saham}

Hasil analisis korelasi berganda didapatkan nilai $\mathrm{R}$ sebesar 0,173 berada pada kategori interval 0,00-0,199 yang menunjukan earning per share (eps) dan price earning ratio (per) secara simultan memiliki hubungan yang sangat rendah terhadap return saham.

Hasil Uji regresi berganda didapatkan persamaan linear $\mathrm{Y}=-0,094+0,000 \mathrm{X}_{1}+(-$ $0,002) \mathrm{X}_{2}$ yang menunjukan apabila earning per share (eps) tetap dinaikan 1 maka return saham akan mengalami kenaikkan sebesar 0,000 , apabila price earning ratio (per) dinaikan 1 maka return saham akan mengalami penurunan sebesar -0,002.

Hasil Analisis Koefisien Determinasi menunjukan bahwa diperoleh $\mathrm{R}^{2}$ (R Square) sebesar 0,030 atau $3 \%$. Hal ini menunjukkan bahwa persentase pengaruh variabel independen earning per share (eps) $\left(\mathrm{X}_{1}\right)$ dan price earning ratio (per) $\left(\mathrm{X}_{2}\right)$ terhadap variabel dependen return saham (Y) adalah 3\% sedangkan sisanya sebesar 97\% dipengaruhi oleh faktor lainnya yang tidak dimasukkan ke dalam penelitian ini.

Berdasarkan hasil analisis uji hipotesis F-test secara simultan earning per share (eps) dan price earning ratio (per) maka diperoleh $\mathrm{F}_{\text {hitung }}$ sebesar 0,461 dan signifikansi 0,664 dan nilai $F_{\text {tabel }}$ sebesar 2,052 sehingga $F_{\text {hitung }} \leq F_{\text {tabel }}(0,461 \leq 2,052)$ dan signifikansi $>0,05(0,664>0,05)$ maka Ho diterima dan Ha ditolak. Dengan demikian dapat disimpulkan bahwa secara simultan tidak terdapat pengaruh signifikan antara earning per share (eps) dan price earning ratio (per) terhadap return saham pada Perusahaan LQ45 yang terdaftar di Bursa Efek Indonesia Periode 2017-2019 .

Berdasarkan latar belakang yang dikutip (Berkontan.co.id - Jakarata. Jumat, 03 Mei 2019 11:15 WIB) dari Perusahaan INTP mengalami penurunan harga saham yang sangat tajam, hal ini disebabkan karena adanya penurunan laba yang disebabkan biaya produksi meningkat dan melemahnya nilai tukar rupiah pada saat itu . Menurut (Arifin, 2018) menyatakan "Ketika tingkat inflasi domestik menurun (relatif terhadap inflasi luar negeri) menyebabkan permintaan akan impor naik sehingga kebutuhan akan mata uang asing (dolar AS) meningkat sehingga nilai tukar rupiah terhadap dolar AS melemah." Ini artinya, terdapat penurunan yang menyebabkan menurunnya daya beli masyarakat karena secara riil tingkat pendapatannya juga menurun, pendapatan menurun akan mengakibatkan laba pun ikut menurun.

Hal ini sejalan dengan penelitian terdahulu yang diteliti oleh Susiani (2017) yang menunjukkan bahwa variabel earning per share (eps) dan price earning ratio (per) tidak memiliki pengaruh signifikan secara simultan ataupun bersama-sama.

\section{KESIMPULAN}

Berdasarkan identifikasi masalah, hipotesis dan hasil pengujian yang telah dilakukan untuk mengetahui pengaruh Earning Per Share (EPS) dan Price Earning Ratio (PER) terhadap Return Saham pada Perusahaan LQ45 yang terdaftar di Bursa Efek Indonesia Periode 2017-2019. Berdasarkan hasil analisis dan pembahasan pada bab sebelumnya dapat disimpulkan sebagai berikut:

1. Hasil uji hipotesis secara parsial menunjukan bahwa tidak terdapat pengaruh signifikan antara Earning Per Share (EPS) terhadap Return Saham pada Perusahaan LQ45 yang terdaftar di Bursa Efek Indonesia Periode 2017-2019. 
2. Hasil uji hipotesis secara parsial menunjukan bahwa tidak terdapat pengaruh signifikan antara Price Earning Ratio (PER) terhadap Return Saham pada Perusahaan LQ45 yang terdaftar di Bursa Efek Indonesia Periode 2017-2019.

3. Hasil uji hipotesis secara simultan menunjukan bahwa tidak terdapat pengaruh signifikan antara Earning Per Share (EPS) dan Price Earning Ratio (PER) terhadap Return Saham pada Perusahaan LQ45 yang terdaftar di Bursa Efek Indonesia Periode 2017-2019.

\section{DAFTAR PUSTAKA}

Gitman, C. J. (2015). Principle Of Managerial Finance,Fourteenth Edition. Singapore: Pearson Education.

Hartono, J. (2017). Teori Portofolio dan Analisis Investasi (Edisi 11). Yogyakarta: BPFE.

Mathilda, M. (2017). Pengaruh Price Earning Ratio dan Price Book Value terhadap Return Saham Pada Perusahaan LQ45. Jurnal Akuntansi.

Rahmawati, A. (2017). Pengaruh Earning Per Share (EPS) Return On Equity (ROE) dan Debt to Equity Ratio (DER) Terhadap Return Saham Pada Perusahaan Food and Beverages yang Terdaftar di Bursa Efek Indonesia (BEI) Periode 2011-2015. EJournal .

Rifa, N. A. (2017). Pengaruh Earning Per Share (EPS) dan Price Earning Ratio (PER) terhadap Return Saham pada Subsektor keramik, porcelen, kaca yang terdaftar di BEI periode 2011-2016. Bandung: repository.upi.edu .

Sartono, A. (2016). Manajemen Keuangan Teori dan Aplikasi. Yogyakarta: BPFE .

Sugiyono, P. D. (2017). Statistika Untuk Penelitian. Bandung: Alfabeta .

Susiani. (2017). Pengaruh Earning Per Share (EPS) dan Price Earning Ratio (PER) terhadap Return Saham Pada Perusahaan SUB-SEKTOR INDUSTRI Periode 20132015. Jurnal Bisnis Indonesia.

Tandelilin, E. (2017). Analisis Investasi dan Manajemen Portofolio. Yogyakarta: BPFE .

Wuldani, S. d. (2016). Pengaruh Price Earning Ratio (PER) dan Earning Per Share Terhadap Return Saham Pada PT. Unilever Indonesia. Jurnal Ekonomi Manajemen . 